\title{
REMOTE SENSING OF A ROMAN POTTERY WORKSHOP. REPORT ON A GEOPHYSICAL SURVEY CARRIED OUT IN CRIKVENICA (ANCIENT AD TURRES, CROATIA)
}

\author{
Fabian Welc ${ }^{1 *}$, Goranka Lipovac Vrkljan², Ana Konestra², Tea Rosić3 \\ ${ }^{1}$ Institute of Archaeology, Cardinal Stefan Wyszyński University,Warsaw,Poland,f.welc@uksw.edu.pl \\ 2 Institute of Archaeology, Zagreb, Croatia,gorankalv@gmail.com,ana.konestra@iarh.hr \\ ${ }^{3}$ Crikvenica Town Museum, Crikvenica, Croatia, kustos@mgc.hr \\ * corresponding author
}

\begin{abstract}
The paper presents results of a geophysical survey conducted in Crikvenica, a town located at the north-eastern Adriatic Sea coast in Croatia. The main aim was to identify extent of a Roman pottery workshop discovered to the north of the present town, at the site known as "Igralište". The performed magnetic and GPR surveys within the area of the modern playground in Crikvenica revealed a large number of anomalies that may be connected with anthropogenic activity during different periods, both in modern and ancient times. The first group consists of anomalies generated by remnants of the modern underground infrastructure. Magnetic and ground-penetrating radar maps revealed anomalies in the north-western part of the modern playground that can be very likely interpreted as remains of a large ceramic kiln dated back to the Roman Period, similar to the kiln discovered during the excavations located further to the north. Finally, the survey performed within the Crikvenica football stadium clearly indicates that the integration of different Ground Penetrating Radar and magnetic methods allows for a detailed and effective identification of buried archaeological structures in large areas.
\end{abstract}

Key words: Remote sensing, archaeology, geophysics, ground-penetrating radar, gradiometer, Crikvenica, Croatia

Manuscript received 2 May 2017, accepted 13 November 2017

\section{INTRODUCTION}

This paper presents results of a geophysical survey conducted in Crikvenica (north-eastern Adriatic Sea coast, Croatia). The main aim of the project was to identify a spatial extent of a Roman pottery workshop located to the north of the modern town, in the area of a football stadium, at the site known as "Igralište", for a better understanding of its spatial organization and production facilities (Fig. 1).

Crikvenica, located at a seashore of the Kvarner Gulf, is probably to be identified with the ancient Ad Turres from Peutinger's Map and other ancient Itineraria (Miller, 1916; Talbert, 2000) and most probably it should be interpreted as a road station along the main artery connecting Aquileia and Salona. In the Antiquity the area was a part of the Dalmatia province, more precisely of its northernmost coastal region, Liburnia (Starac, 2000; Suić, 2003).
The site of the pottery workshop is located near the mouth of the Dubračina Stream and a gorge connecting it with the Vinodol valley, a rare flysch area within the dominantly karst landscape of the Kvarner (Benac et al., 2006, Figs 1, 2), the area with thick clay sediments. Data derived from finds excavated within the site stresses a link to this resource-rich hinterland. In fact, tile stamps bearing the name of the owner of the ceramic workshop - Sextus Metilius Maximus - indicate also a type of property that it belonged to a saltus, seen as an estate devoted to farming, but also to pasture and forest exploitation (Soricelli, 2004) (Fig. 3: 1, 2). Moreover, the array of several new types of amphorae produced in the workshop and intended to contain goods from Sextus' estate can be interpreted as containers for olive oil, wine and fish products, giving indication on the economy of the area (Lipovac Vrkljan, 2011). Timber for fuel and also clay needed for ceramic production must have been likewise brought from the Vindol 

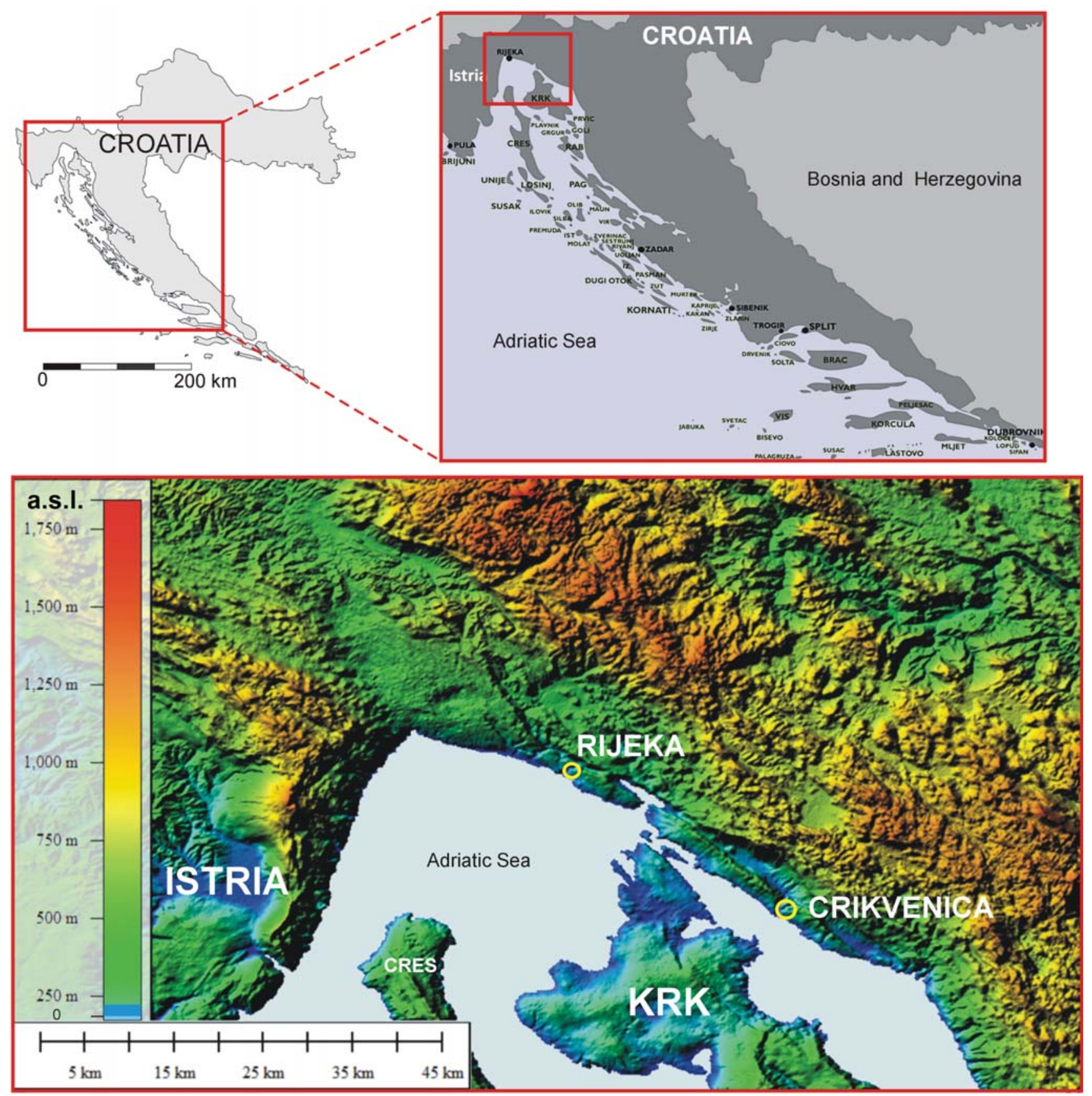

Fig. 1. Maps showing the location of Crikvenica, Croatia (Drawing: F. Welc, based on DEM Landsat 8 data and other open source data).

valley. Finally, Crikvenica's hinterland provided also land transportation infrastructure necessary to market ceramics and pottery, as well as amphora-borne commodities, by means of the road running through it.

\section{HISTORY OF EXCAVATIONS}

The "Igralište" site was first identified in 1983 (Starac, 1991), to be definitely interpreted as a ceramic workshop in 2004 (Lipovac Vrkljan, 2007, 2009). Systematic excavations followed, carried out from 2006 to 2015 by the Institute of Archaeology in Zagreb, allowing for a better understanding of the layout of this complex, production features and products array (Lipovac Vrkljan et al., 2016). Though isolated ceramic kilns were known within the Dalmatia province, Crikvenica pottery production complex is the first identified large scale figlina producing a wide repertoire of pottery and ceramics, spanning from amphorae, fine and common wares, to several types of ceramic building materials and particular shapes and objects (incense burners, loom weights, etc.) (Lipovac Vrkljan, 2011; Ožanić Roguljić, 2012).

Excavations allowed for a definition of the general layout of the workshop and a spatial organization of its installations, which was of key significance in a reconstruction 

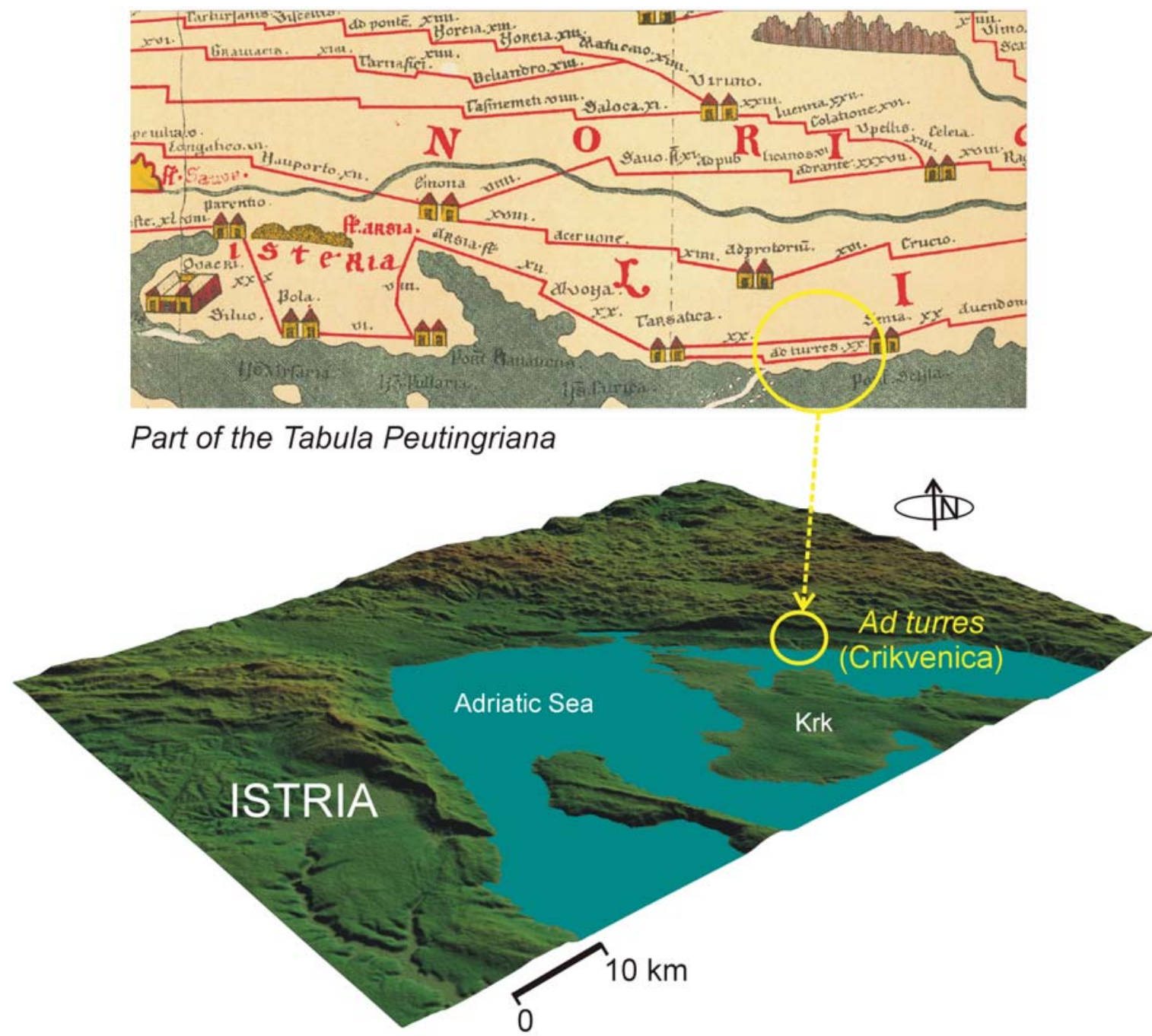

Fig. 2. Part of the Tabula Peutingeriana showing the location of Ad Turres and a DEM model of the northern coast of the Adriatic Sea, showing the same area with the location of modern Crikvenica (most probably ancient $A d$ Turres) (Drawing: F. Welc, DEM model based on Landsat 8 data).

of the production technology. It has been ascertained that production processes were organized within an enclosed space (the western, eastern and northern fencing walls as well as a gate have been uncovered) with several roofed and open spaces with smaller auxiliary rooms, hosting also a clay basin and at least four kilns (Fig. 4: 1,2). Based on analogous features such as kiln typology, dimensions and spatial layout, an existence of more kilns was postulated. These data, along with a rest of the workshop layout, makes it possible to presume its size, even though not all of its parts can be excavated.

A road system was uncovered within the complex, the main path stretching along the N-S axis from the gate located in the northern wall. This road connected the figlina with the Vinodol valley, whereas within the complex it functioned as a pathway connecting the northern and presumably, the southern part of the workshop in the kiln area (Lipovac Vrkljan et al., 2016). As a layout of the area where the workshop was set up had changed significantly since the Antiquity (i.e. both due to natural fluvial deposition and artificial fillings; a riverbed regulation changed a course of the Dubračina Stream and the area around it) (Crmarić et al., 2007), a harbour system, perhaps combining sea and river navigation, can be expected in the area to the south of the complex, towards the modern seashore.

The facility operated from the second half of the $1^{\text {st }}$ century $\mathrm{BC}$ until the end of the $2^{\text {nd }}$ century $\mathrm{AD}$, though the area was in use later as well, as indicated by the $4^{\text {th }}$ century burials uncovered above the figlina layers (Konestra and Ožanić Roguljić, 2016). A study in the wider Kvarner Gulf and the northern Dalmatian areas proved that products from Crikvenica were commercialized in an area stretching from Rijeka in the north to Šibenik in the south, including a coastal hinterland and nearby islands within a distance of about 400 km (Lipovac Vrkljan and Ožanić Roguljić, 2013).

Excavations carried out at the "Igralište" site concentrated in an area of ca. $1800 \mathrm{~m}^{2}$, but it was estimated that no more than a half of the complex has been uncovered, the rest of which must have stretched further south, below a modern football playground. In fact, during laying of modern installations below the football field, ancient remains were documented but never excavated (Dračić, 

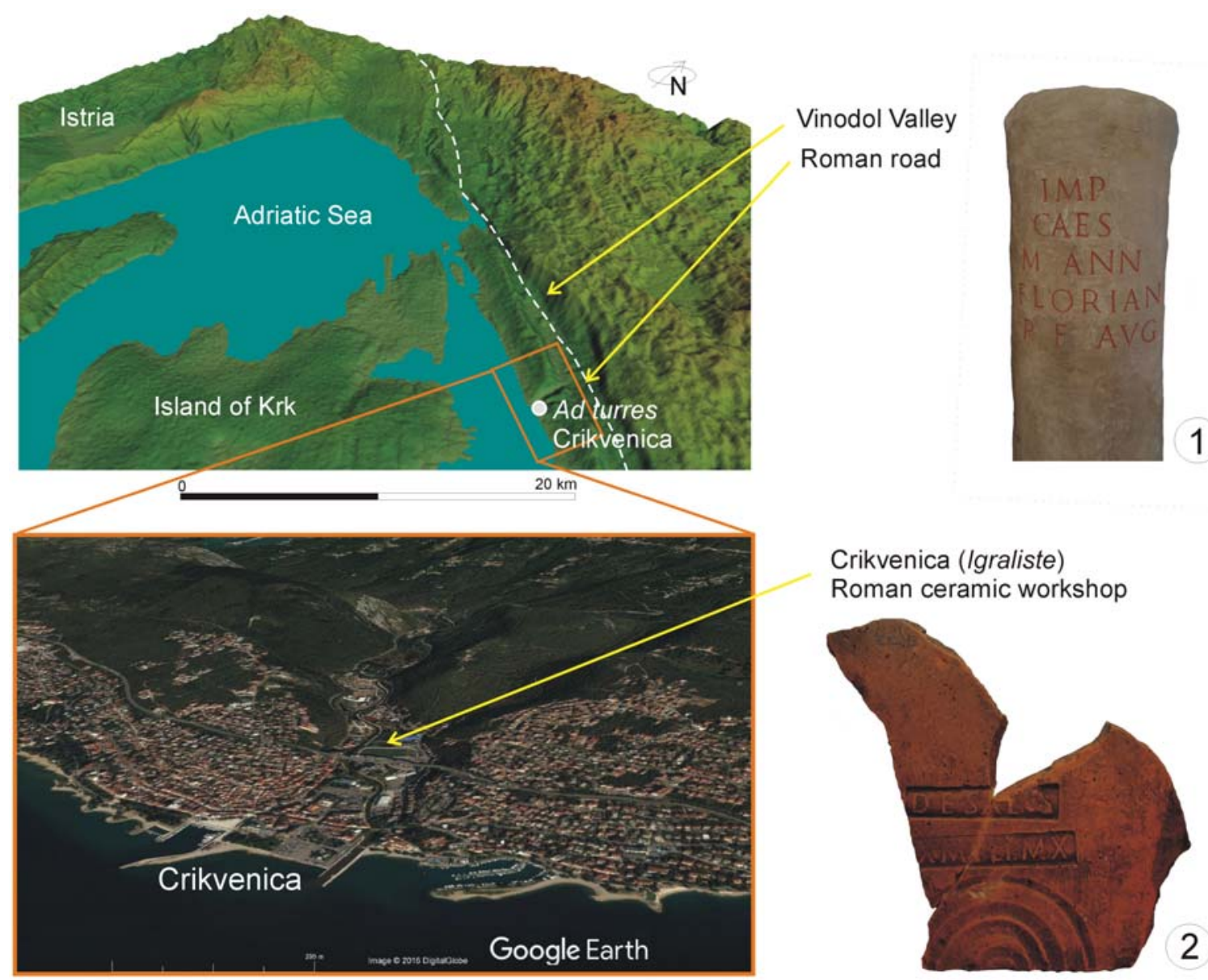

Fig. 3. Upper left, DEM model showing the location of Crikvenica (Ad Turres), the Vinodol Valley and the possible course of an ancient Roman road connecting Italia with the Dalmatia province: 1 - Roman milestone found in the Vinodol region (Crikvenica Town Museum, photo F. Welc). Lower left, satellite photo showing the location of the Roman pottery workshop in Crikvenica: 2 - ceramic roof tile with the stamp of Sextus Metilius Maximus, owner of the workshop at the "Igralište" site (Crikvenica Town Museum, photo: F. Welc).

1991), whereas stratigraphy of the southern part of the excavated area offered some indications of features being present more to the south as well (Lipovac Vrkljan and Šiljeg, 2008). An extensive geophysical survey was carried out in 2016 in the area covered by the modern football ground. The main purpose of this survey was to confirm presence of ancient features and in particular, of other kilns.

\section{METHODS}

Geophysical prospecting techniques were initially designed for geological sciences, but nowadays they are also widely and successfully used in archaeology (Coneyers and Leckebusch, 2010; Welc et al., 2017). In addition to geoelectrical methods, also magnetic and ground-penetrating radar (GPR) techniques are very often employed in archaeological surveys. It has to be emphasized that these methods are not universal (Milsom, 2003; Owsin, 2009; Coneyers and Leckebusch 2010; Welc et al., 2017). For this reason these techniques are better considered as being complementary to one another (Coneyers and Leckebusch 2010). This is due to the simple fact that GPR and magnetic methods have their own limitations and strong depend on geology of the examined site, which can significantly influence a final outcome of the survey (see among others: Conyers, 2016; Welc et al. 2017). During the survey in Crikvenica, two geophysical methods were used interchangeably due to limitations of both methods and a strongly transformed terrain; application of a single method could not guarantee good results (see more in: Milsom, 2003; Owsin, 2009; Toushmalani, 2010; Welc et al., 2017).

GPR is a very mobile and effective method of subsurface geophysical prospection, especially for archaeology (see among others, Imai et al., 1987; Conyers, 2013, 2016a; Mieszkowski et al., 2014; Welc et al., 2014a, b, 2015; Welc and Mieszkowski, 2015). The GPR device, composed of a transmitting-receiver antenna and a steering device, emits electromagnetic waves to a ground with high and ultra-high frequency radio waves $(10 \mathrm{MHz}-2 \mathrm{GHz})$ and registers impulses reflected from lithological boundaries and buried objects. Wave reflection from geological boundaries depends on soil lithology and its saturation with water. In highly unfavourable conditions, i.e. low-resistivity soils (thick beds of mud, silt or clay), damping of the electromagnetic wave may be high enough to decrease the prospection 


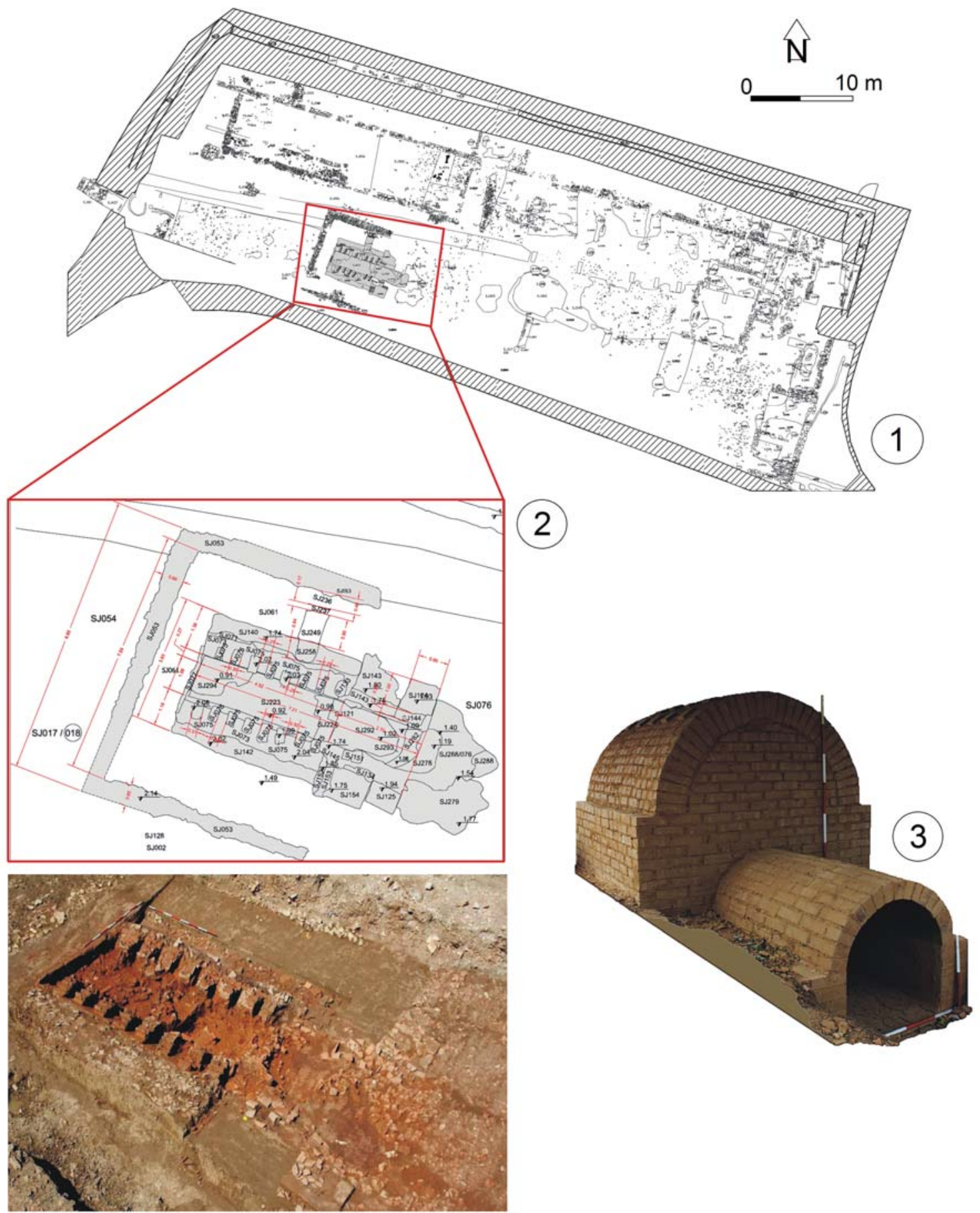

Fig. 4. 1: Sketch of the excavated part of the Roman ceramic workshop at the "Igralište" site (Crikvenica). 2: Detailed sketch and photo of the pottery kiln uncovered at the "Igralište" site. 3: Replica of the pottery kiln from the "Igralište" site, reconstructed according to archaeological remains at a scale of $1: 2$ (After: Lipovac et al., 2012).

depth to several metres or even to a dozen centimetres (Conyers 2013, 2016; Welc et al., 2017).

RAMAC GPR system, produced by the Mala Geoscience was used in the survey. The prospection was carried out with application of a bimodal screened transmitting antenna with a nominal frequency of $500 \mathrm{MHz}$. The device was equipped with a computer using Ramac Ground Vision software designed for the acquisition of measurement data directly in the field. All obtained radargrams (reflection profiles) were then processed in professional GPR software, among others Reflex-Win of the Sendmeier Company. Several processing procedures were applied: Running average, Dewow (variant of the running average procedure), DC - shift, Subtract-mean, Gain (AEG gain, manual gain), Move start time, Bandpass frequency, Background removal, Average xy filter, Complex trace analysis, Deconvolution, Migration and Static correction. Their main aim was the enhancement of the usable signal in relation to the background 

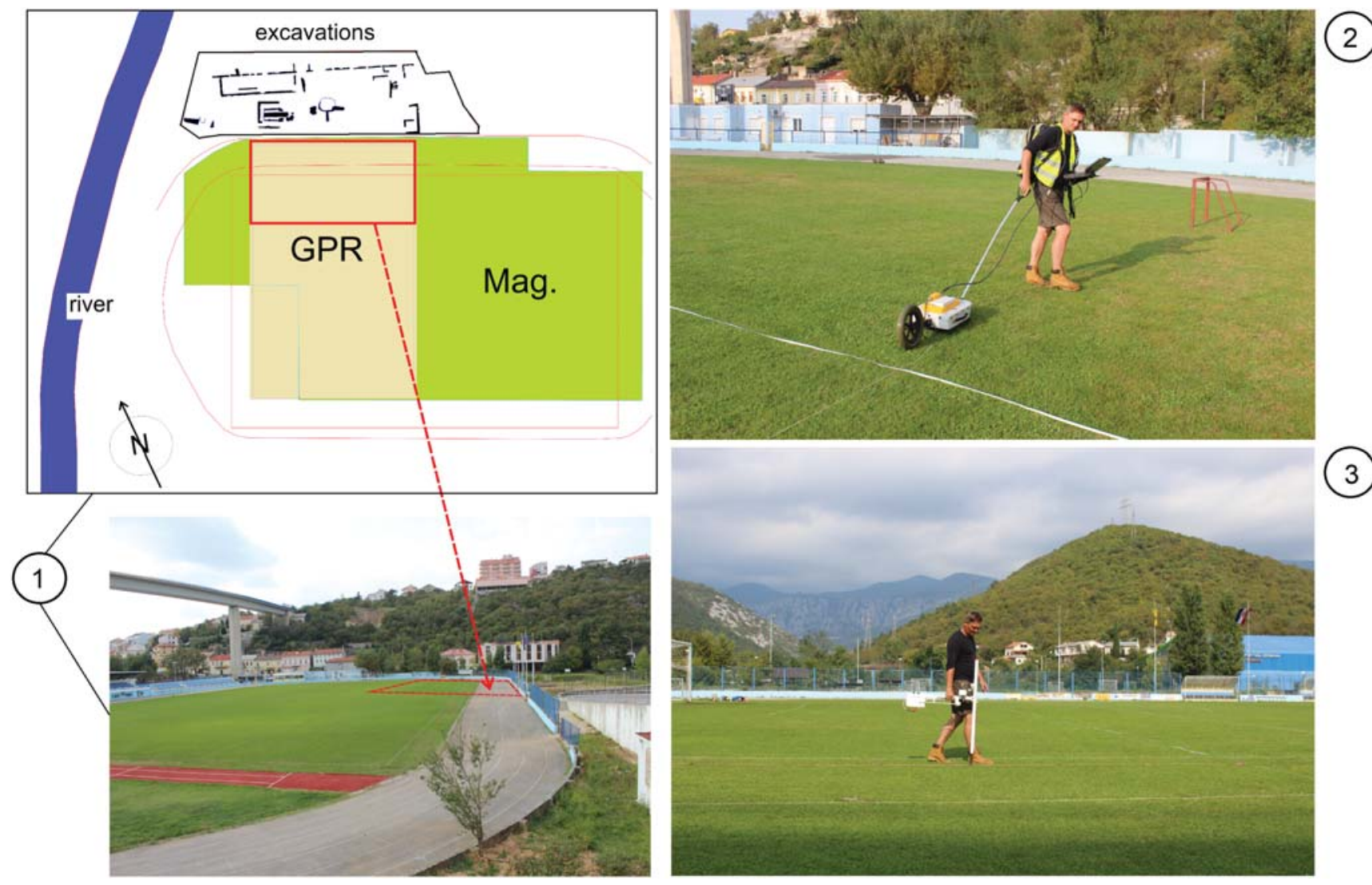

Fig. 5. Sketch-map showing the measurement polygons on the area of the football playing ground in "Igralište" site (1) surveyed by ground-penetrating radar (2) and gradiometer (3) (Drawing: F. Welc).

(i.e. noise). Crucial was also the improvement of correlation and continuity of the usable reflexes, minimization of random noise and elimination of the determined disruptions. The last procedure of processing arranged reflection profiles in quasi 3D block diagrams using the Reflex View $3 D$ data interpretation mode. A topographic correction was applied when the area had significant altitude differences. Smaller ones, less than $0.3 \mathrm{~m}$ in, allowed preparing the 3D models of underground structures without a need of topographic correction. A final effect of processing and filtering was a 'purified' measuring material in the form of reflection profiles and GPR depth plans used for further archaeological interpretations.

The propagation velocity of the electromagnetic wave in the ground was calculated at $0.05 \mathrm{~m} / \mathrm{ns}$, based on analysis of diffraction hyperboles geometry. It allowed corrections of a depth scale on GPR images (reflection profiles and time slices). However, this method required averaging characteristics of a geological medium; therefore a resulting depth scale did not correspond to the actual depth of buried objects or structures. This error can be estimated at $\pm 0.30 \mathrm{~m}$ in this particular case and it should be taken into account during interpretation of GPR data.

In contrast to GPR, the magnetometer (gradiometer) is used to detect changes in the Earth's magnetic field caused by concentration of ferrous-based minerals in a soil (Won and Huang, 2004). During magnetic surveys using gra- diometers, different magnetic properties of soils and archaeological features are recorded as variations against a background of the Earth's magnetic field. Changes in the magnetic field connected with archaeological features are usually very weak and produce anomalies, which can be measured in values from $0.2 \mathrm{nT}$ (nanoTesla) if compared with a magnetic field strength of $48000 \mathrm{nT}$ (Toushmalani, 2010). Magnetic surveys are very useful for identification of past settlements with such features as ditches, hearths, kilns, furnaces or large pits (Jordan, 2009; Herbich, 2012; Fassbinder, 2015). The Grad601 gradiometer produced by Bartington was used during fieldwork in Crikvenica. All profiles were separated at $0.5 \mathrm{~m}$ from each other. All data were processed using Terra Surveyor software produced by the DW Consulting company (https:/www.dwconsulting. nl/TerraSurveyor.html).

\section{RESULTS}

\section{Magnetic prospection}

The magnetic survey was located in a football stadium, covering its entire playing ground, which is completely overgrown by a thick grass (Fig. 5). From the north, the survey zone bordered with a concrete wall that separates the football ground from the excavation area. Magnetic 

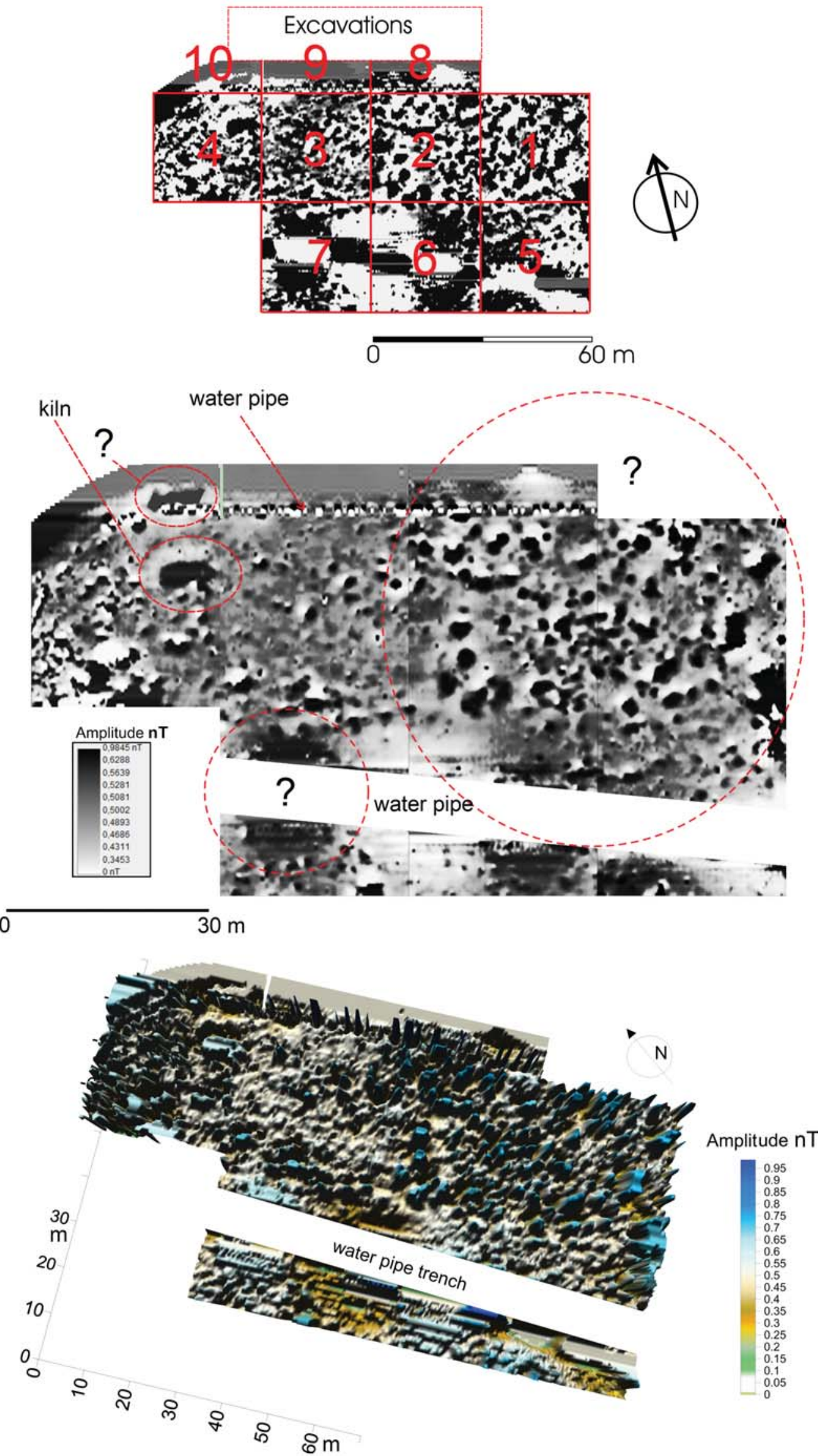

Fig. 6. Results of magnetic survey performed in the Crikvenica football playground in the form of map of magnetic anomalies distribution in negative mode (upper image) and 3D colour mode (lower image) (Drawing and processing: F. Welc). 


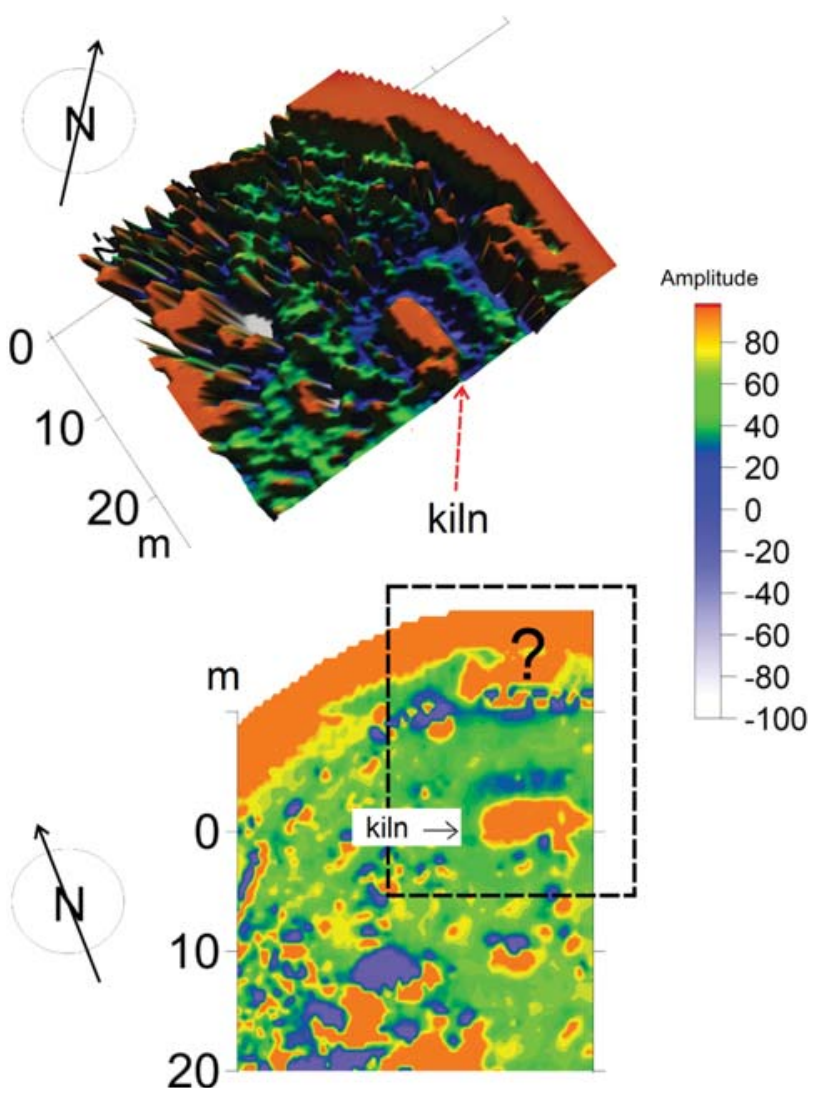

Fig. 7. Magnetic image of the ceramic kiln, most probably very similar to the one discovered during excavations. Another structure visible more to the north is difficult to interpret based only on magnetic measurements (Processing and drawing: F. Welc).

measurements were arranged in 6 squares with dimensions of $30 \times 30 \mathrm{~m}$ and four smaller additional polygons. In the eastern part of the study area, a concentration of anomalies was noted, which were clearly indicated on a magnetic map as dark-coloured areas (Fig. 6). Most of them should be associated with presence of an orchard or clusters of trees, dated most probably at $19^{\text {th }}-20^{\text {th }}$ centuries in the eastern part of the area. Nevertheless, it cannot be excluded that these anomalies are generated by ash or other waste concentrations, connected with some other activities and different use of the area (Figs 5, 6).

In the southern part of the study area a distinct wide and linear zone of anomalies was clearly visible, oriented west-east (areas 5-7, Fig. 6). The zone coincided perfectly with a water pipe documented on maps of technical infrastructure. Unfortunately, a wide extent of this zone did not allow distinguishing any other anomalies such as those that could be associated with the past human activity. In the south-western part of the study area only an oval-shaped anomaly was visible, which could be interpreted as remains of a large structure (area 7, Fig. 6).

In the north-western part of the playground, which directly borders the excavation area, the anomalies were characterized by high amplitudes. Some of them should be undoubtedly attributed to a modern underground technical infrastructure (drainage system running along the northern margin of the playground). The most important results were yielded by measurements performed within the polygon 4 (Fig. 6), where two zones of very high amplitude anomalies were detected. A close-up of this area revealed an oval-shaped structure, which was located approximately $13 \mathrm{~m}$ from another structure (Fig. 7). The length of these two features could be estimated at $12 \mathrm{~m}$ and the width at $2.5 \mathrm{~m}$. While an unambiguous interpretation of the northern anomaly was difficult, based on magnetic measurements (mostly due to strong disruptions generated by a metal fence of the playground) only, the southern one seemed to be a magnetic image of a large pottery kiln, very similar to the one that was discovered during the excavations. The walls of this structure seemed partly to have been burnt out. The interior was filled entirely with ash and burnt material, therefore it generated anomalies, characterized by very high amplitudes on a magnetic map. Outside the kiln, a wall surrounding the structure from the south-west and north-east was also visible, similar to the wall surrounding the excavated kiln (Figs 4, 7).

\section{GPR prospection}

GPR profiling was performed within a polygon adjacent to the excavation area and oriented along north-south (Fig. 5). All measurements were made using the $500 \mathrm{MHz}$ bimodal antenna. Results of the GPR profiling were largely complementary to the magnetic survey, but were not entirely synchronous, mainly due to geology of the ground. The area occupied today by the playground was repeatedly flooded in the past by the nearby Dubračina Stream, thus the ground was mainly composed of alluvial soils that strongly absorbed electromagnetic waves, particularly in a turf zone, that was eroded (during construction of the stadium infrastructure) and additionally covered by a thick layer of clay soil enhancing grass growth, and as a result reducing the depth range of the prospecting to values not exceeding $2 \mathrm{~m}$.

GPR plans (time slices) prepared for the depth $0.40-$ $0.84 \mathrm{~m}$ revealed anomalies generated by shallowly buried pipes (Fig. 8). A very distinctive linear anomaly oriented along the west-east axis was noted in the northern part of the polygon and it was an echo of drainage installation, also evident on magnetic plans (Fig. 6). This installation was dug deep into the ground, because its course can be traced to a depth of $1.5 \mathrm{~m}$.

A GPR anomaly defined as the object A coincided with a high amplitude point revealed in the same place on a magnetic plan (Fig. 6). This is an echo of underground structure, visible on GPR plans at the depth 0.60-1.80 m. Combined GPR and magnetic data (Fig. 9) indicated clearly that the discussed anomaly was generated by the pottery kiln, very similar in size to the structure uncovered during the excavations (Fig. 4). Comparison of the newly discovered structure to those of the excavated kiln, allowed for distinguishing a firing chamber and possible remains of the praefurnium (fire box) (Fig. 10).

Analysis of reflection profiles indicated positions, in 

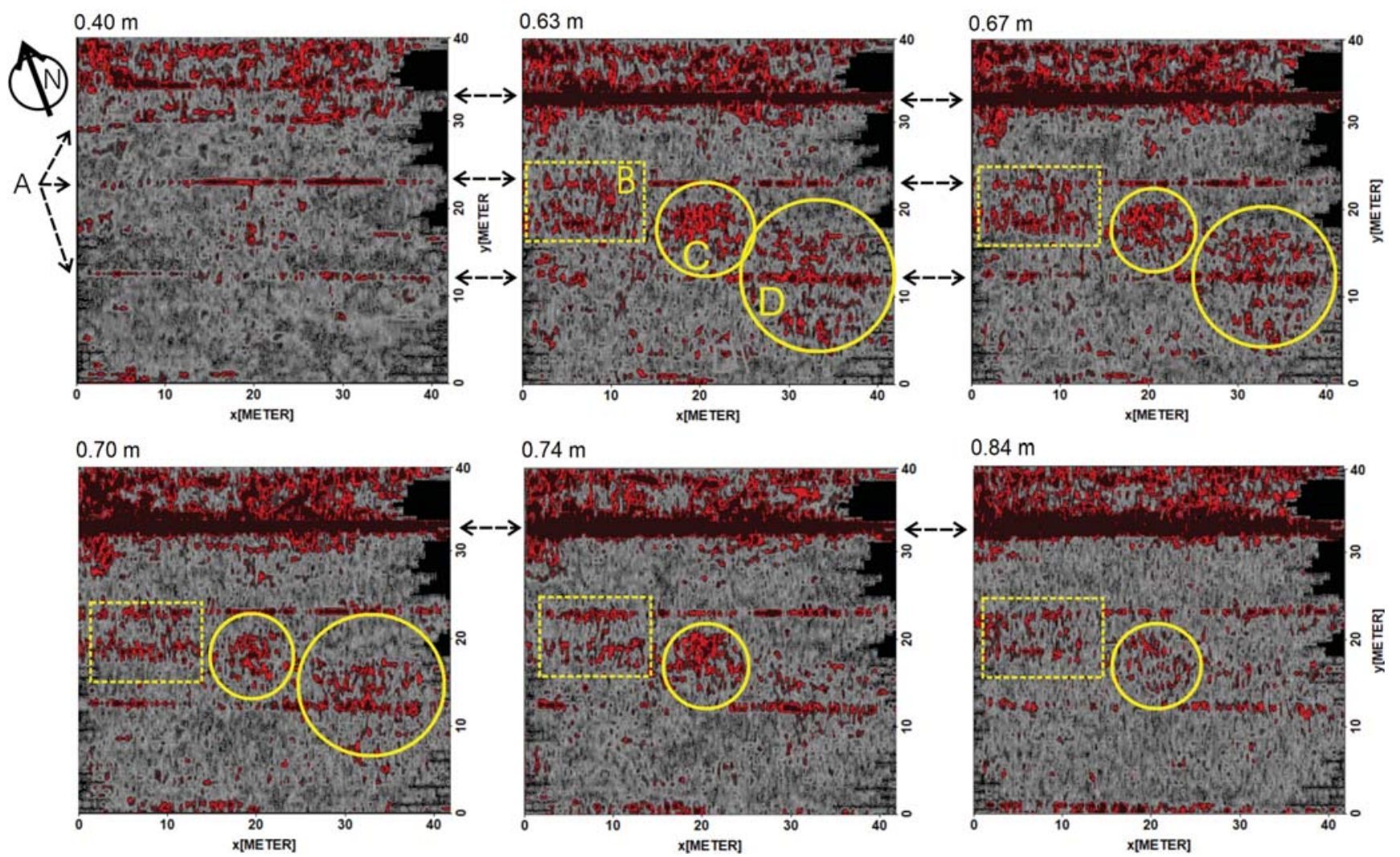

Fig. 8. GPR plans (= time slices) prepared for the area located directly to the south of the excavation zone. The time slices revealed linear anomalies generated by shallowly buried pipes (A). In the NW part of the area an anomaly is visible (B), which is generated by the kiln, similar in shape and dimensions to the structure uncovered nearby during recent excavations. The anomaly marked as D is most probably, connected with an ancient road, a part of which was discovered during the excavations. The anomaly D is accumulation of stone rubble (Processing and drawing: F. Welc).
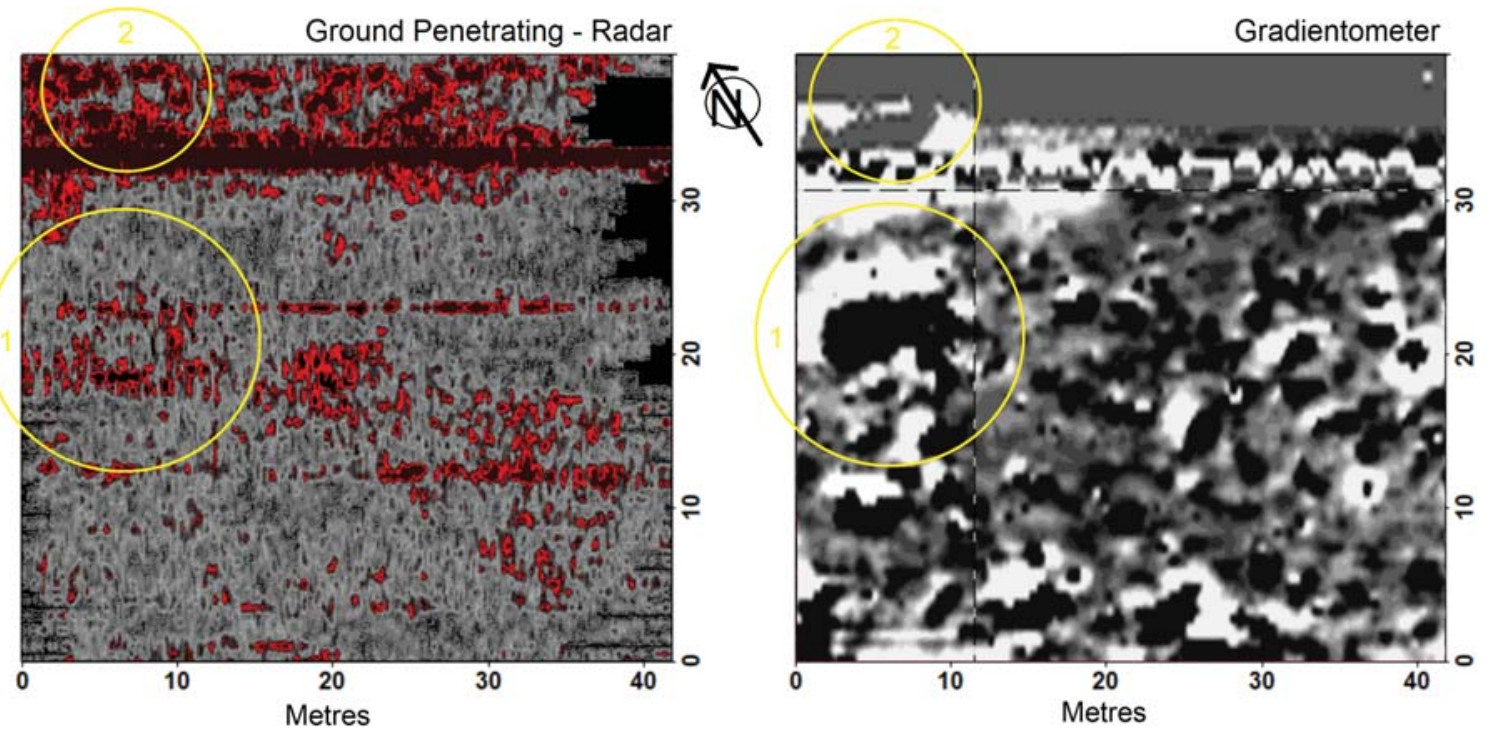

Fig. 9. The anomaly detected on GPR plans coincides with the anomaly revealed in the same place on magnetic plans. Combined GPR and magnetic data suggest that this (1) - anomaly zone is probably generated by a pottery kiln similar to that uncovered nearby during excavations; (2) - anomaly zone - much more difficult to interpret, basing on data obtained from the geophysical survey only (Processing and drawing: F. Welc).

which remains of kiln walls were preserved (visible as a series of diffraction hyperboles (Fig. 11: 2). GPR profiles indicated also we location of several reflection surfaces, which are most probably linked with an ancient road, a part of which was discovered during the excavations (Fig. 11: 1).
Figure 9 presents a comparison between magnetic and GPR data in the area directly bordering the excavations (polygon 4). In the case of maps of magnetic anomalies distribution, only an outline of kiln remains could be traced. These data did not supply information about the third di- 

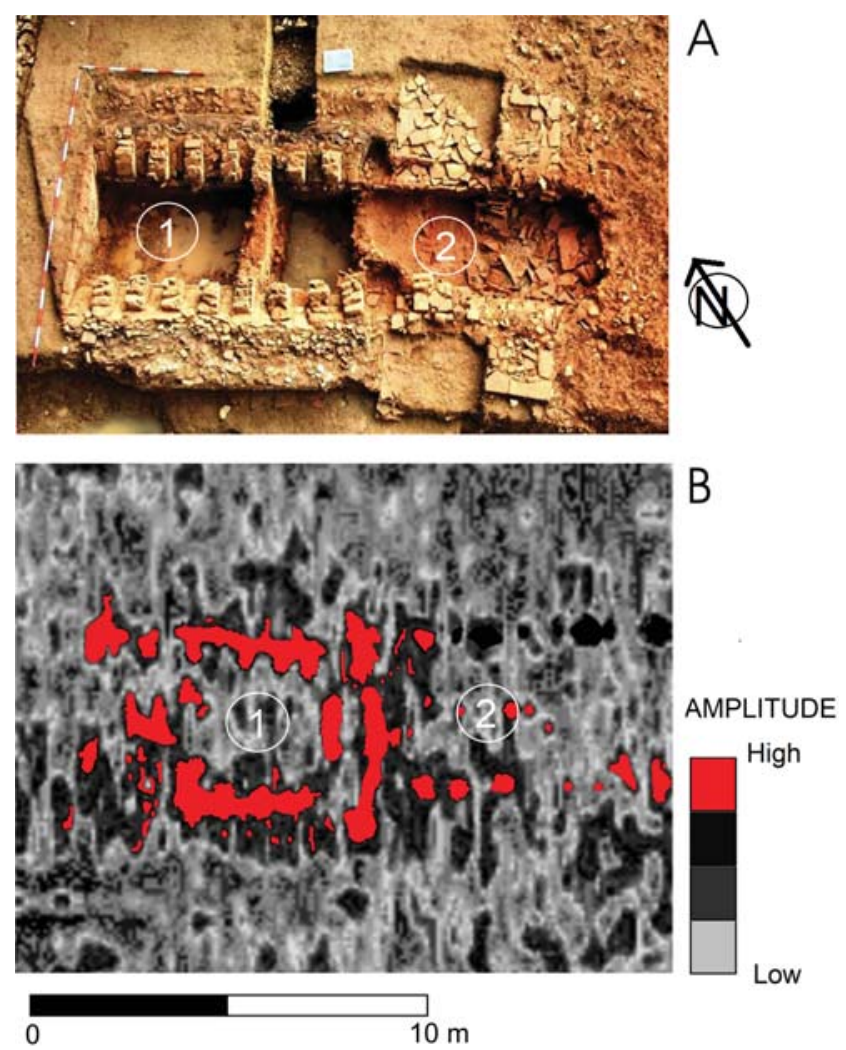

Fig. 10. Aerial photo of the pottery kiln discovered during the excavations (A) and GPR "image" of an analogous structure located to the south of the excavation zone (B). Based on the results of excavations on the prepared GPR plan, the firing chamber (1) and the possible remains of the fire box (2) can be distinguished. (Photo: Institute of Archaeology, Drawing and processing: F. Welc).

mension, i.e. the depth and the vertical cross-sections of recognized anomalies. Such information came from GPR surveys (Conyers 2013, 2016a; Welc et al., 2017). Magnetic maps, GPR time slices and reflection profiles produced images of very different buried construction materials. In our case, GPR reflections were produced by real (physical) remains of a kiln. In contrast, magnetic anomaly maps presented mostly a large concentration of ferromagnetic minerals, such as ashes and burnt remains of walls or trench foundations. The excavations proved that all walls and infilling of the kiln were composed of bricks and tiles - burnt clay (Lipovac Vrkljan and Šiljeg, 2008). In contrast, GPR depth slices indicated real kiln remains composed of walls constructed from large burnt bricks. These walls generated high anomalies on the GPR time slices and sets of characteristic reflection hyperbolas on the reflection profiles (Fig. 11).

Summarizing, the performed magnetic and GPR measurements in the area of the football playground at the "Igralište" site revealed a number of anomalies that could be associated with anthropogenic activity in different periods, both in modern and ancient times.

The first group consists of linear anomalies generated mostly by remnants of a modern underground infrastructure. Magnetic and GPR plans revealed a course of main water pipes crossing the area along the SE-NW axis and strings of modern pipes under the playground. Slightly older was a cluster of numerous point anomalies visible on magnetic plans in the eastern part of the study area, most likely generated by remains of trees or shrubs from the $19^{\text {th }}-20^{\text {th }}$ century. It seems also probable that these anomalies were generated by archaeological features. Some of these features could be interpreted as rubbish pits or waste accumulations, similar to the features discovered during the excavations (Šiljeg et al., 2013), but they could also indicate features that were not connected with the workshop production activity.

Magnetic and GPR maps have revealed concentration of anomalies that could be very likely interpreted as remains of a pottery kiln dated back to the Roman Period in the north-western part of the field. The kiln (marked as the structure A) belongs most probably to the same workshop discovered during excavations directly to the north of the playground. This structure could be hardly traced on GPR plans, because the playground was levelled and covered with a thick bed of a clayey soil that strongly attenuated electromagnetic waves. Magnetic plans revealed that the installation was surrounded by a wall or a courtyard from the north, west and south.

Unfortunately, results of the geophysical survey did not allow assessing the southern border of the area occupied by antique workshops due to presence of an extensive trench dug for a water pipe and additional installations, which generated a wide area with very high amplitude magnetic anomalies. Due to unfavourable conditions, GPR measurements conducted in the south-western part of the playground did not yield the expected results.

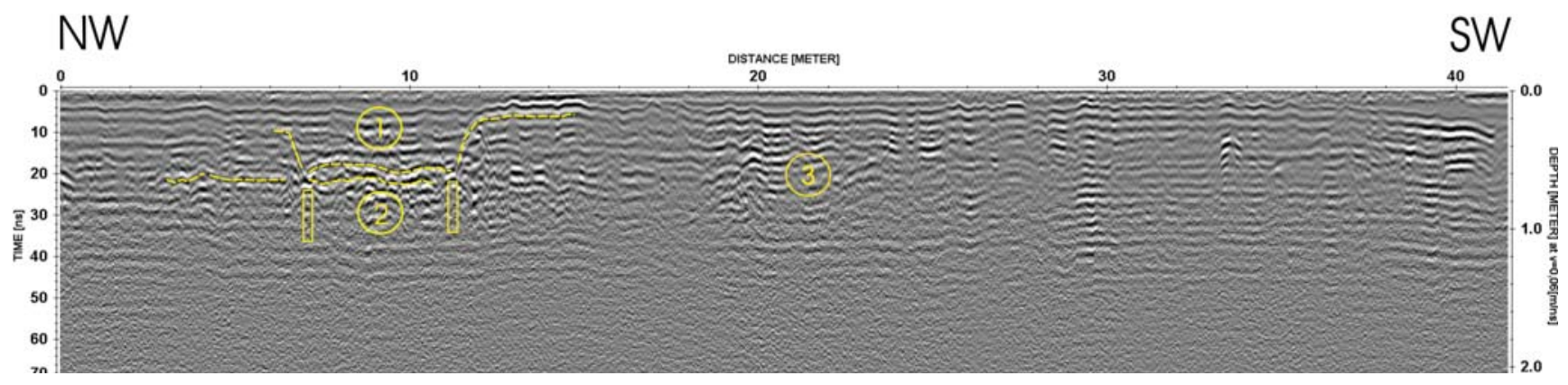

Fig. 11. The reflection profiles have revealed the positions, in which remains of the newly located kiln are preserved (visible as a series of diffraction hyperboles and reflection surfaces). 1: Shallow hollow above the kiln. 2: Main firing chamber of the kiln. 3: Several reflection surfaces, which should probably be linked with the remains of an ancient road (Drawing and processing: F. Welc). 


\section{FINAL CONCLUSIONS AND ARCHAEOLOGICAL IMPLICATIONS}

The survey performed in the Crikvenica football playground clearly indicates that integration of different geophysical methods allows for detailed and effective identification of buried archaeological structures in large areas. The integration of magnetic and GPR techniques provides mutually consistent results, but in some cases they supply complementary information, especially when magnetic and GPR data are compared. In the case of maps of magnetic anomalies distribution, buried walls and modern infrastructure elements can be easily traced, but not all of them are visible on GPR plans. By contrast, magnetic data do not deliver information about the third dimension, i.e. a depth and vertical cross-sections of the newly located anomalies. Such information is provided by GPR records only. The two methods supply images of different buried construction materials. GPR reflections are produced by remains of stone foundations, demolition layers and even a shallow trench filled with stone rubble. In contrast, magnetic anomaly maps present concentrations of ferromagnetic minerals such as destruction layers, firing places and foundation trenches (even if no physical wall remains are present inside). The integration of magnetic and GPR results is extremely important, as both techniques create images of very different buried materials (Conyers, 2013).

One of the features that most markedly characterizes the Crikvenica pottery workshop is a spatial organization of its productive features and a "standardized" layout that can be compared to similar installations in other areas of the Roman world, mostly in Italy, with which it also shares a selection of a natural setting (Vitali, 2007; Manacorda and Pallecchi, 2012; Pallecchi, 2012). These details, such as fencing, layout and nature of the roofed and open spaces, grouping of kilns and overall symmetry characteristics of these installations (Pallecchi, 2012), allowed for estimating the original extent of the site and focusing a research towards identification of those features that were not exposed during the excavations.

The most prominent feature that could be hypothesized based on archaeological evidence (remains of another wall are visible within the profile to the south of the excavated kiln) is the existence of one or more large kilns similar to that excavated in the south-western part of the site (Fig. 4: 1, 2). In fact, such types of kilns (Cuomo di Caprio IIb), usually associated with ceramic building materials and amphora production, often come in pairs or in larger groups so as to optimize production (Pallecchi, 2012). As the aforementioned anomaly detected in the western part of the study area (Figs 6,7$)$ presents shape and dimensions very similar to the excavated kiln (Fig. 10), this makes interpretation of a set of kilns located in the western part of the complex and developed from the north to the south very probable. Moreover, an additional feature detected around the kiln and interpreted as a wall surrounding it from three sides, provides evidence of a similar construction method of this and the excavated kiln.
Data collected during the geophysical survey indicates that in Antiquity the area of the workshop extended well below the modern football playground, confirming supposition built on the old discoveries and scanty archaeological indications, though due to numerous later activities its remains are probably poorly preserved. Nevertheless, these results shed new light on the possible productive capacity of the workshop, altering estimates and production quantification, and providing new data on economic capacities not only of the figlina but of the wider estate, which it was a part of.

\section{Acknowledgments}

This paper stems from the activities carried out within the project RED-Roman Economy in Dalmatia: production, distribution and demand in the light of pottery workshops, funded by the Croatian Science Foundation (IP-11-2013-3973).

\section{BIBLIOGRAPHY}

Benac, Č., Ružić, I., Žic, E., 2006. Ranjivost obala u području Kvarnera. Pomorski zbornik 44/1, 201-214.

Conyers, B.L., 2013. Ground-Penetrating Radar for Archaeology. 3rd Edition. Altamira Press.

Conyers, B.L., 2016. Ground-Penetrating Radar for Geoarchaeology. Wiley and Blackwell.

Conyers, B.L., 2016a. Ground-Penetrating Radar Mapping Using Multiple Processing and Interpretation Methods. Remote Sensing 8, 562: doi:10.3390/rs8070562

Conyers, B.L., Leckebusch, J., 2010. Geophysical archaeology research agendas for the future: Some Ground-penetrating Radar examples. Archaeological Prospection 17, 117-123.

Crmarić, R., Juračić, M., Benac, Č., Ružić, I., 2007. Sedimentacija na ušću Dubračine i Novljanske ričine, Vinodolski kanal. In: Gereš, D. (Ed.), Zbornik radova. 4. hrvatska konferencija o vodama. Hrvatske vode i Europska unija - izazovi i mogućnosti, 297-302, Hrvatske vode, Opatija.

Dračić, A., 1991. Naselje na ušću Dubračine od II do VI vijeka. Vindolski zbornik 6, 55-76.

Fassbinder, W.E., 2015. Seeing beneath the farmland, steppe and desert soil: magnetic prospecting and soil magnetism. Journal of Archaeological Science 56, 85-95.

Herbich, T., 2012. Geophysical methods and landscape archaeology. Egyptian Archaeology 41, 11-14.

Imai, T., Sakayama, T., Kanemori, T., 1987. Use of Ground-Probing Radar and Resistivity Surveys for Archaeological Investigations. Geophysics 52, 137-150.

Jordan, D., 2009. How effective is geophysical Survey? A regional review. Archaeological Prospection 16, 77-90.

Konestra, A., Ožanić Rogiljić, I., 2016. Illuminating the Way: Later Roman Factory Lamp from a Grave Context in Crikvenica. In: Lipovac Vrkljan, G., Ožanić Roguljić, I., Ugarković, M. (Eds), Roman and Late Antique Lamps: Production and Distribution, Contacts on the Mediterranean. Proceedings of the international round table, Zagreb $2^{\text {nd }}$ February 2015, 128-136, Institut za arheologiju, Zagreb.

Lipovac Vrkljan, G., Šiljeg, B., Ožanić Roguljić, I., Konestra, A., 2012. Experimental Archaeology - a replica of a Roman pottery kiln. Annales Instituti Archaeologici 6, 149-154.

Lipovac Vrkljan, G., 2007. Otkriće lokalne rimske keramičarske radionice u Crikvenici. Annales Instituti Archaeologici 3, 83-87. 
Lipovac Vrkljan, G., 2009. L'officina ceramica di Crikvenica. In: Pesavento Mattioli, S., Carre, M.-B. (Eds), Oilo e pesce in epoca romana. Produzione e commercio nelle regioni dell'alto Adriatico. Atti del convegno (Padova, 16 febbraio 2007), 309-314, Edizioni Quasar, Roma.

Lipovac Vrkljan, G., 2011. Lokalna keramičarska radionica Seksta Metilija Maksima u Crikvenici - Crikveničke amfore ranog dna. In: Lipovac Vrkljan, G., Radić Rossi, I., Šiljeg, B. (Eds), Rimske keramičarske i staklarske radionice. Proizvodnja i trgovina na jadranskom prostoru. Zbornik I. međunarodnog arheološkog kolokvija, Crikvenica (23-24. listopada 2008), 3-18, Institut za arheologiju, Muzej grada Crikvenica, Crikvenica.

Lipovac Vrkljan, G., Ožanić Roguljić, I., 2013. Distribucija crikveničke keramika kao prilog poznavanju rimskog gospodarstva. Senjski zbonik 40, 255-270.

Lipovac Vrkljan, G., Šiljeg, B., 2008. Exploration of the Igralište site in Crikvenica in 2007. Annales Instituti Archaeologici 4, 88-92.

Lipovac Vrkljan, G., Valent, I., Konestra, K., Ožanić R.I., 2016. Roman pottery production complex in Crikvenica - conclusive research in 2015. Annales Instituti Archaeologici, 12, 144-151.

Manacorda, D., Pallecchi, S., 2012. Le fornaci romane di Giancola (Brindisi). In: Manacorda, D., Pallecchi, S. (Eds), Edipuglia, Bari.

Mieszkowski, R., Welc, F., Budziszewski, J., Migal, W., Bąkowska, A., 2014. Preliminary results of the ground penetrating radar (GPR) prospection in the area of the prehistoric flint mine Borownia, southeastern Poland. Studia Quarternaria 31 (2), 115-123.

Miller, K., 1916. Itineraria Romana: Römische Reisewege an der Hand der Tabula Peutingeriana, Stuttgart.

Milsom, J., 2003. Field Geophysics. 3. Edition. 232 pp., Wiley.

Owsin, J.A., 2009. Field guide to geophysics in archaeology. Springe

Ožanić Roguljić, I., 2012. Pottery from the workshop of Sextus Metilius Maximus (Crikvenica-Igralište/Ad Turres, Northern Dalmatia). Rei Cretariae Romanae Fautorum Acta 42, 125-132.

Pallecchi, S., 2012. Appunti sull'organizzazione del lavoro negli stabilimenti romani per la produzione di ceramica pesante. In: $\mathrm{Ci}$ acci, A., Rendini, P., Zifferero, A. (Eds), Archeologia della vite e del vino in Toscana e nel Lazio. Dalle tecniche dell'indagine archeologica, alle prospettive della biologia molecolare, 469-484, All'Insegna del Giglio, Firenze.

Šiljeg, B., Lipovac Vrkljan, G., Ožanić Roguljić, I., Konestra, A., 2013. Crikvenica - Ad turres, Results of Systematic Archaeological Excavations of the Roman Pottery Workshop at the Igralište Site in 2012. Annales Instituti Archaeologici 9, 121-130.

Soricelli, G., 2004. Saltus. In: Storchi Marino, A. (Ed.), Economia, amministrazione, fiscalità nel mondo romano. Ricerche lessicali, 97-123, Edipuglia, Bari.

Starac, A., 2000. Rimsko vladanje u Histriji i Liburniji II, Liburnija. Arheološki muzej Istre, Pula.

Starac, R., 1991. Antička keramika sa lokaliteta "Igralište" u Crikvenici, Vinodolski Zbornik 6, 21-25.

Suić, M., 2003. Antički grad na istočnom Jadranu. Golden marketing - Tehnička knjiga - Institut za arheologiju, Zagreb.

Talbert, R.J.A. (Ed.), 2000. Barrington Atlas of the Greek and Roman World, with Map-by-Map Directory, Princeton University Press.

Toushmalani, R., 2010. Application and Limitation of Geophysical Techniques in Archaeology. Australian Journal of Basic and Applied Sciences 4 (12), 6440-6449.

Vitali, D., 2007. Le fornaci e le anfore di Albinia, Primi dati su produzioni e scambi dalla costa tirrenicaal mondo Gallico, Albinia I., Atti del Seminario internazionale, Ravenna, 6-7 maggio 2006, Vitali, D. (Ed.), 25-46, Università di Bologna, Dipartimento di archeologia, Bologna.

Welc, F., Mieszkowski, R., 2015. Unknown Ancient Funerary Structures Discovered in West Saqqara (Egypt) Using Ground-Penetrating Radar (GPR). Études et Travaux 28, 201-215.

Welc F., Mieszkowski, R., Budziszowski, J., Wysocki, J., Kowalczyk, S., Nalazek, C., 2014a. Applicability of ground - penetrating radar method (GPR) in non - invasive archaeological prospection: the case of three types sites in Poland. Fontes Archaeologici Posnanienses-Annales Musei Archaeologici Posnaniensis 50 (2), 147-161.

Welc, F., Mieszkowski, R., Kowalczyk, S., Trzciński, J., 2014b. Applicability of Ground Penetrating Radar on desert archaeological sites: A case study from the Saqqara necropolis in Egypt. Studia Quarternaria 31 (2), 133-143.

Welc, F., Mieszkowski, R., Conyers, L.B., Budziszewski, J., Jedynak, A., 2016. Reading of Ground-Penetrating Radar (GPR) images of Prehistoric flint mine: case study from Krzemionki Opatowskie Archaeological Site in Central Poland. Studia Quaternaria 33 (2), 78-69.

Welc, F., Mieszkowski, R., Trzciński, J., Kowalczyk, S., 2015. Western Section of the 'Dry Moat' Channel Surrounding Step Pyramid Complex in Saqqara in the Light of Ground-penetrating Radar Prospection. Archaeological Prospection 22/20, 293-305.

Welc, F., Mieszkowski., Lipovac Vrkljan, G., Konestra, A., 2017. An attempt to integration of different geophysical methods (magnetic, GPR and ERT): A Case study from the Late Roman settlement on the Island of Rab (Croatia). Studia Quaternaria 34, 47-59.

Won, I.J., Huang, H., 2004. Magnetometers and electromagnetometers. The Leading Edge 23, 448-451. 